\title{
KOLABORASI ORANG TUA DAN GURU MELALUI KUBUNGORTU DALAM PEMBENTUKAN KARAKTER SISWA SD
}

\author{
Henny Sri Rantauwati \\ SD Negeri Delegan 3 \\ henysri70@gmail.com
}

\begin{abstract}
Abstrak
Penelitian ini bertujuan untuk memaparkan: (1) peran orang tua dalam meningkatkan karakter disiplin dan tanggung jawab peserta didik melalui kubungortu; (2) peran guru dalam meningkatkan karakter disiplin dan tanggung jawab peserta didik melalui kubungortu; dan (3) Kolaborasi orang tua dan guru dalam meningkatkan karakter disiplin dan tanggung jawab peserta didik melalui kubungortu. Penelitian ini merupakan penelitian studi kasus yang dilaksanakan pada bulan Juli-November 2019.Subjek penelitian adalah peserta didik, orang tua peserta didik, dan guru yang dipilih dengan teknik purposive sampling. Teknik pengumpulan data menggunakan wawancara kepada peserta didik, orang tua peserta didik, dan guru. Keabsahan data menggunakan triangulasi sumber dan teknik analisis data menggunakan analisis interaktif Miles dan Huberman. Hasil penelitian menunjukkan bahwa: (1) peran orang tua peserta didik dalam meningkatkan karakter disiplin dan tanggung jawab peserta didik di rumah adalah proaktif yaitu dengan strategi mengenalkan, menanamkan, dan membiasakan karakter disiplin dan tanggung jawab peserta didik dengan membuat jadwal belajar di rumah dan mengkomunikasikan melalui kubungortu; (2) peran guru dalam meningkatkan karakter disiplin dan tanggung jawab peserta didik di sekolah adalah memberikan teladan, penghargaan, dan membiasakan melalui kegiatan-kegiatan pembiasaan yang menumbuhkan kegiatan disiplin dan tanggung jawab serta mengkomunikasikan melalui kubungortu; (3) kolaborasi orang tua dan guru dalam meningkatkan karakter disiplin dan tanggung jawab peserta didik secara langsung dan tidak langsung terjalin baik, terbukti dengan peran aktif orang tua peserta didik dalam mendukung program-program sekolah seperti POS (Paguyuban Orang Tua Siswa) dan kubungortu. Hal ini berdampak pada peningkatan karakter disiplin dan tanggung jawab peserta didik.
\end{abstract}

Kata kunci: karakter disiplin, peran orang tua, peran guru, kolaborasi

\section{PENDAHULUAN}

Rendahnya karakter disiplin dan tanggung jawab bangsa ini membutuhkan perhatian dan partisipasi dari semua pihak. Perhatian dan kepedulian terhadap karakter telah dirumuskan pada fungsi dan tujuan pendidikan bagi masa depan bangsa Indonesia. Sebagaimana yang tercantum pada pasal 3 Undang-Undang 
Nomor 20 Tahun 2003 tentang Sistem Pendidikan Nasional sebagai berikut: "Pendidikan nasional berfungsi mengembangkan kemampuan dan membentuk watak serta peradaban bangsa yang bermartabat dalam rangka mencerdaskan kehidupan bangsa, bertujuan untuk berkembangnya potensi peserta didik agar menjadi manusia yang beriman dan bertakwa kepada Tuhan Yang Maha Esa, berakhlak mulia, sehat berilmu, cakap, kreatif, mandiri, dan menjadi warga negara yang demokratis serta bertanggung jawab". Oleh karena itu, partisipasi dari semua pihak dibutuhkan guna mewujudkan fungsi dan tujuan pendidikan nasional tersebut.

Menumbuhkembangkan karakter bangsa yang bermoral bukan sekadar persoalan penyampaian teori tentang ilmu etika dan moral sebagai mata pelajaran di sekolah, melainkan membangun kebiasaan yang berkesinambungan dari hari ke hari. Bagi seorang peserta didik, untuk membangun kebiasaan tersebut membutuhkan figur panutan yang dapat dijadikan teladan. Keteladanan dari orang sekitarnya menjadi dasar pembentukan konsep moral yang dimiliki peserta didik. Pembentukan kepribadian seorang anak selama ini banyak dipengaruhi oleh faktor dari dalam dirinya, lingkungan sekitar, pola asuh orang tua, dan pendidikan di sekolah.

Usia sekolah dasar merupakan tahap penting bagi pelaksanaan pendidikan karakter, bahkan hal yang merupakan fundamental bagi kesuksesan pengembangan karakter anak. Pada usia sekolah dasar, anak mengalami perkembangan fisik dan motorik termasuk perkembangan kepribadian, watak emosional, intelektual, bahasa, budi pekerti, dan moralnya yang bertumbuh pesat. Oleh karena itu jika menghendaki pendidikan karakter dapat berhasil maka pelaksanaannya harus dimulai sejak dini.

Daya adaptasi anak usia sekolah dasar ditandai dengan kemampuannya bergaul dengan teman-teman barunya dari berbagai latar belakang, menghormati guru, dan menaati tata tertib sekolah. Orang tua dan guru harus berperan aktif dalam mendorong anak untuk mengendalikan emosi dan mengontrol diri melalui ucapan dan perilaku sesuai dengan norma yang berlaku, serta menegur anak jika perilaku anak dianggap menyimpang dari kesepakatan yang sudah dibuat. 
Keberhasilan pendidikan bagi anak sangat ditentukan oleh berbagai unsur lingkungan yang ada dalam lingkungan pendidikan anak. Lingkungan pendidikan anak tersebut meliputi lingkungan keluarga, lingkungan sekolah, dan lingkungan masyarakat yang terkenal dengan Tri Pusat Pendidikan.

Mengingat betapa besar pengaruh terhadap keberhasilan pendidikan anak, maka sangat diperlukan kolaborasi atau kerja sama yang efektif antara sekolah, orang tua dan masyarakat agar terbina hubungan timbal balik dalam rangka membentuk karakter peserta didik sesuai dengan harapan bersama yaitu menciptakan generasi yang berkarakter terutama karakter disiplin dan tanggung jawab. Sebagaimana kolaborasi antara orang tua dan guru di SD Negeri Delegan 3 Prambanan Sleman.

SD Negeri Delegan 3 merupakan salah satu SD Negeri yang terletak di Dusun Polangan, Kelurahan Sumberharjo, Kecamatan Prambanan, Kabupaten Sleman telah menjalin kerjasama atau kolaborasi yang baik dengan orang tua peserta didik. Hal ini dibuktikan dengan beberapa hal yang mendukung keberhasilan baik bidang akademik maupun bidang non akademik.

Di samping itu dalam pembentukkan karakter disiplin dan tanggung jawab pada peserta didik, SD Negeri Delegan 3 telah melakukan kolaborasi orang tua dan guru dengan berbagai kegiatan seperti pendampingan orang tua terhadap anaknya ketika belajar, pelaporan/komunikasi dan penandatanganan orang tua peserta didik dan guru melalui buku penghubung orang tua peserta didik.

\section{Pendidikan Karakter}

Pendidikan karakter merupakan pendidikan ihwal karakter, atau pendidikan yang mengajarkan hakikat karakter dalam ketiga ranah cipta, rasa, dan karsa. Megawangi (Barnawi, 2017) mendefinisikan pendidikan karakter sebagai sebuah usaha untuk mendidik anak-anak agar dapat mengambil keputusan dengan bijak dan mempraktikkannya dalam kehidupan sehari-hari sehingga mereka dapat memberikan kontribusi yang positif kepada lingkungannya.

Pendidikan karakter adalah suatu sistem penanaman nilai-nilai karakter kepada warga sekolah yang meliputi komponen pengetahuan, kesadaran atau 
kemauan, dan tindakan untuk melaksanakan nilai-nilai tersebut, baik terhadap Tuhan Yang Maha Esa (YME), diri sendiri, sesama, lingkungan, maupun kebangsaan sehingga menjadi manusia insan kamil. Dalam pendidikan karakter di sekolah, semua komponen (stakeholders) harus dilibatkan, termasuk komponenkomponen pendidikan itu sendiri, yaitu isi kurikulum, proses pembelajaran dan penilaian, kualitas hubungan, penanganan atau pengelolaan mata pelajaran, pengelolaan sekolah, pelaksanaan aktivitas atau kegiatan ko-kurikuler, pemberdayaan sarana, prasarana, dan, pembiayaan,dan,ethos kerja seluruh warga dan lingkungan sekolah.

Mengutip pendapat Lickona (Samani, 2013: 50) "pendidikan karakter secara psikologis harus mencakup dimensi penalaran berlandaskan moral (moral reasoning), perasaan berlandaskan moral (moral felling), dan perilaku berasaskan moral (moral behavior). Thomas Lickona menyatakan dalam bukunya Educating for Character (Barnawi dan Arifin, 2017: 55-56) karakter yang baik meliputi mengetahui yang baik, menginginkan yang baik, dan melakukan yang baikkebiasaan pikiran, kebiasaan hati, dan kebiasaan tindakan. Berdasarkan pengertian tersebut, sesungguhnya pendidikan karakter bukan sekadar pengajaran atau penatarantentang nilai-nilai karakter. Formula pendidikan karakter meliputi aspek pemahaman (kognitif) tentang kebaikan, aspek motivasi atau keinginan (afektif) untuk berbuat baik, action (tindakan) berbuat baik (psikomotorik).

Dari definisi-definisi di atas, ternyata pendidikan karakter dihubungkan dengan rencana/program sekolah, yang dirancang bersama lembaga masyarakat yang lain, untuk membentuk secara langsung dan sistematis perilaku peserta didik. Pendidikan karakter berorientasi pada pembentukan manusia yang berakhlak mulia dan berkepribadian luhur.

\section{Komponen Pendidikan Karakter}

Pendidikan karakter merupakan sistem penanaman nilai-nilai karakter kepada peserta didik dan penerapan pendidikan karakter dalam kehidupan peserta didik dimana saja, sehingga dapat memberikan kontribusi yang positif kepada lingkungannya. Generasi muda perlu memperoleh penanaman nilai-nilai 
tradisional dari orang dewasa yang menaruh perhatian kepada mereka yaitu para anggota keluarga, guru, dan masyarakat. Mereka juga memerlukan teladan dari orang dewasa mengenai integritas kepribadian dan kebahagiaan hidup.

\section{Tujuan Pendidikan Karakter}

Pusat Kurikulum Badan Penelitian dan Pengembangan Kementrian Pendidikan Nasional (dikutip dalam Samani, 2013: 52) "Pendidikan karakter bertujuan membentuk bangsa yang tangguh, kompetitif, berakhlak mulia, bermoral, bertoleran, bergotong royong, berjiwa patriotik, berkembang dinamis, berorientasi ilmu pengetahuan dan teknologi yang semuanya dijiwai oleh iman dan takwa kepada Tuhan yang Maha Esa berdasarkan Pancasila”.

Karakter tidak sekadar sikap yang dicerminkan perilaku, tetapi juga terkait dengan motif yang melandasi sesuatu sikap. Dalam hal ini ada pengaruh lingkungan. Faktor penentu keberhasilan untuk mengatasi krisis watak ditentukan oleh masing-masing kita sendiri, dimulai dengan lingkungan keluarga dan lingkungan tempat tinggal, serta lingkungan kerja kemuadian meluas menjadi lingkungan kota dan lingkungan negara. Hal ini harus menjadi sebuah gerakan nasional yang dimaknai bahwa seluruh usaha bersama dengan satu tujuan akhir. Lingkungan keluarga menjadi tempat penting bagi pembangunan karakter. Peran orang tua di rumah secara prinsip tetap memiliki posisi paling sentral (Hendarman, 2019: 13).

\section{Nilai-Nilai Pendidikan Karakter}

Nilai-nilai pendidikan karakter yang dikembangkan Kementerian Pendidikan Nasional (Peraturan Menteri Pendidikan dan Kebudayaan Nomor 20 Tahun 2018 tentang Penguatan Pendidikan Karakter pada Satuan Formal) bahwa penguatan pendidikan karakter didasarkan pada lima nilai utama. Lima nilai utama yang saling berkaitan yaitu religius, nasionalis, mandiri, gotong-royong, dan integritas. Ditegaskan juga pada pasal 6 ayat (1) pentingnya optimalisasi fungsi kemitraan tripusat pendidikan, yaitu antara sekolah, orang tua, dan masyarakat untuk saling bahu-membahu dalam penyelenggaraan penguatan 
karakter, dengan pendekatan yang berbasis kelas, budaya sekolah, dan masyarakat (Hendarman, 2019: 34-41).

\section{Karakter Disiplin}

Kemendiknas mendeskripsikan disiplin sebagai tindakan yang menunjukkan perilaku tertib dan patuh pada berbagai ketentuan dan peraturan. (Kemendiknas, 2010: 9). Menurut Husdarta, (2010: 110), disiplin berarti kontrol penguasaan diri terhadap impuls yang tidak diinginkan atau proses mengarahkan impuls pada suatu cita-cita atau tujuan tertentu untuk mencapai dampak yang lebih besar. Sebagai indikator karakter disiplin Kemendiknas mengungkapkan bahwa indikator karakter disiplin meliputi: 1) membiasakan hadir tepat waktu; 2) membiasakan mematuhi aturan; 3) menggunakan pakaian sesuai dengan ketentuan. Mengutip menurut AS. Moenir (Hudiyono, 2012: 74) disiplin adalah ketaatan terhadap aturan. Disiplinisasi adalah usaha yang dilakukan untuk menciptakan keadaan di suatu lingkungan kerja yang tertib, berdaya guna, dan berhasil guna melalui suatu sistem pengaturan yang tepat.

Dari definisi-definisi tersebut dapat disimpulkan bahwa disiplin adalah suatu kondisi yang tercipta melalui proses latihan yang dikembangkan menjadi serangkaian perilaku yang di dalamnya terdapat unsur-unsur ketaatan, kepatuhan, kesetiaan, ketertiban dan semua itu dilakukan sebagai tanggung jawab yang bertujuan untuk mawas diri. Sikap disiplin peserta didik di dalam belajar tercermin dalam kedisiplinan penggunaan waktu, baik waktu dalam belajar ataupun waktu dalam mengerjakan tugas, serta mentaati tata tertib.

\section{Karakter Tanggung Jawab}

Karakter tanggung jawab diwujudkan dalam kemampuan membuat rencana, mempersiapkan diri, dan selanjutnya mengambil tindakan serta keberanian menanggung konsekuensi logis dari tindakan tersebut. Tanggung jawab berisi kesiapsediaan untuk melakukan perjuangan dan pengorbanan untuk mewujudkan cita-cita. 
Tanggung jawab adalah sikap ketika peserta didik harus bersedia menerima akibat dari apa yang telah diperbuat. Tanggung jawab juga merupakan sikap di mana peserta didik harus konsekuen dengan apa yang telah dipercayakan kepadanya.

Berdasarkan kajian kebutuhan tentang pembinaan nilai akhlak mulia yang diturunkan dari Kebijakan Nasional Pendidikan diidentifikasi nilai indikator tanggung jawab pada jenjang Sekolah Dasar kelas Atas: (1) menyelesaikan tugastugas yang diberikan dengan baik; (2) apabila melakukan kesalahan, mau mengakui dan memperbaikinya (Kemdikbud, 2017).

\section{Peran Orang Tua dalam Membentuk Karakter Disiplin dan Tanggung Jawab pada Peserta Didik}

Menurut Walgito (2010) bahwa perilaku manusia dipengaruhi oleh lingkungan dan pengaruh dari dalam diri sendiri. Menurut Rosyi Datus Saadah (Kurniawan, 2017: 64) keluarga merupakan lingkungan pendidikan yang cukup efektif dan efisien dalam upaya mengantarkan generasi penerus dalam membekali kemampuan diri dengan sebaik-baiknya sehingga dapat menjadi generasi yang andal, terampil, dan tangguh.

Orang tua sebagai orang yang pertama yang mengenal, mengerti dan memahami sifat-sifat baik dan buruk anak-anaknya, apa saja yang mereka sukai dan apa saja yang mereka tidak sukai perlu hati-hati dan waspada dalam penanaman karakter seperti karakter religius, disiplin, sopan, santun, toleransi, berani, rajin, tanggung jawab terhadap anaknya.

Disiplin sebagai salah satu sikap yang harus dikembangkan pada anaknya di antaranya disiplin waktu meliputi waktu ibadah, belajar, istirahat, bermain, dan lain-lain. Disiplin kebersihan meliputi kegiatan menjaga kebersihan rumah dan pakaian. Disiplin keamanan meliputi menjaga keamanan rumah dari hal-hal yang membahayakan. 


\section{Metode Pembentukan Karakter Disiplin dan Tanggung Jawab pada Peserta}

Didik

Untuk membentuk karakter disiplin dan tanggung jawab pada peserta didik dapat diusahakan dengan jalan: 1) pembiasaan, 2) teladan, 3) penyadaran, 4) pengawasan atau kontrol (Bisri, 2016: 44). Empat hal di atas dapat dijelaskan seperti berikut ini:

1) Pembiasaan, peserta didik dibiasakan melakukan sesuatu yang baik, tertib, teratur dan bertanggung jawab.

2) Teladan, keteladanan orang tua merupakan hal sangat urgen terhadap perkembangan karakter peserta didik selain interaksi dan pola asuh. Karena keteladan orang tua akan menjadi cetak biru bagi peserta didik beraksi, bertindak, merasa dan berpikir. Seorang peserta didik akan selalu meniru apa yang dilihat, didengar, dan yang dirasa dari orang tuanya.

3) Penyadaran, kewajiban orang tua untuk memberikan penjelasan tentang karakter disiplin dan tanggung jawab sesuai dengan kemampuan dan usia peserta didik.

4) Pengawasan atau kontrol, perlunya pengawasan dan kontrol dari orang tua dan guru terhadap peraturan dan tata tertib yang dilakukan peserta didik jika ada yang melanggar.

\section{Peran Guru dalam Membentuk Karakter Disiplin dan Tanggung Jawab pada Peserta Didik}

Dalam dunia pendidikan, budi pekerti adalah hal yang paling penting. Kompetensi akademik peserta didik harus seiring dengan akhlaknya. Untuk itu, guru harus memberikan teladan budi pekerti melalui ucapan, perilaku, dan tindakan yang dapat memberikan pengalaman yang menarik bagi peserta didik. Budi pekerti yang dicontohkan guru merupakan sistem nilai yang mengakomodasi keunikan perilaku peserta didik, sekaligus membimbing peserta didik agar berbudi pekerti seperti yang dinginkan sekolah (Hudiyono, 2012: 27). Kompetensi guru sebagai agen pembelajaran pada jenjang pendidikan dasar dan menengah meliputi 
kompetensi paedagogik, kompetensi kepribadian, kompetensi professional, dan kompetensi sosial (Hudiyono, 2012: 25)

Berdasarkan kompetensi-kompetensi di atas, seorang guru sebagai penentu keberhasilan pembelajaran dan pembentukkan karakter terutama karakter disiplin dan tanggung jawab, maka guru harus memahami tugas dan fungsinya sesuai dengan kompetensi yang dimiliki.

\section{Kolaborasi Orang Tua dan Guru dalam Membentuk Karakter Disiplin dan Tanggung Jawab Peserta Didik}

Tri pusat pendidikan adalah tiga pusat lingkungan pendidikan yang terdiri dari lingkungan keluarga, sekolah, dan masyarakat. Orang tua memiliki tanggung jawab untuk mendidik anak-anaknya di rumah, guru bertanggung jawab mendidik peserta didik di sekolah untuk itu sangat perlu sekali hubungan yang baik antara orang tua dan guru agar informasi dan pengajaran yang didapat peserta didik tidak berbeda dan masyarakat itu sendiri yang mengawali adanya gagasan untuk terus mewujudkan watak dan kepribadian yang baik dalam kehidupan bermasyarakat yang luas.

Orang tua perlu ikut andil dalam membantu sekolah untuk mengembangkan semua aspek perkembangan yang sudah dimiliki peserta didik dengan cara menjalin kolaborasi dengan guru. dengan adanya kerja sama itu orang tua akan dapat memperoleh pengetahuan dan pengalaman dari guru dalam mendidik anak-anaknya. Karena guru bukan hanya mengembangkan kecerdasan peserta didik saja akan tetapi juga berusaha membentuk kepribadian peserta didik menjadi manusia yang berwatak baik dan berakhlak.

Keterlibatan orang tua merupakan suatu proses dimana orang tua menggunakan segala kemampuan mereka guna keuntungan mereka sendiri, peserta didik, dan program yang dijalankan peserta didik. Kurniawan (2017) menjelaskan bahwa keluarga menjadi wahana untuk mendidik, mengasuh, dan mensosialisasikan sesuatu pada anak, mengembangkan kemampuan seluiruh anggotanya agar dapat menjalankan fungsinya di masyarakat dengan baik. 
Keluarga merupakan aspek penting untuk menanamkan karakter pada anak sehingga anak mempunyai karakter yang baik.

Menyadari besarnya tanggung jawab orang tua dalam pendidikan karakter seorang anak maka orang tua juga seyogianya bekerja sama dengan sekolah sebagai lingkungan pendidikan formal untuk membantu pendidikan anak tersebut. Dalam hubungannya dengan sekolah, orang tua mesti berkoordinasi dengan baik dengan sekolah tersebut (Kurniawan, 2017: 223).

Sebagai hasil jika tidak terjalinnya komunikasi yang baik antara kolaborasi antara guru dan orang tua adalah tujuan pembelajaran tidak tercapai dengan optimal. Karena kolaborasi antara guru dan orang tua merupakan suatu program yang terpenting dalam lembaga pendidikan khususnya anak usia dini. Kolaborasi yang baik antara guru dan orang tua akan terbentuk jika komunikasi yang efektif antara guru dan orang tua.

\section{METODE}

Penelitian ini bertujuan mendapat gambaran tentang kolaborasi orang tua dan guru dalam membentuk karakter disiplin dan tanggung jawab pada peserta didik meliputi: peran orang tua dalam pendidikan karakter peserta didik di rumah, peran guru dalam pendidikan karakter pederta didik di sekolah, dan kolaborasi orang tua dan guru dalam pendidikan karakter peserta didik. Berkaitan dengan hal tersebut maka yang digunakan dalam penelitian ini adalah penelitian kualitatif dengan pendekatan studi kasus tunggal.

Penelitian ini merujuk pada pandangan Creswell (Mulyana, 2002: 204) yang memberi definisi penelitian kualitatif sebagai berikut: untuk memperoleh gambaran yang kompleks dan menyeluruh diperoleh dari potret keadaan nyata, analisis kalimat yang diperoleh dari informan, serta tingkah laku dari latar penelitian sebagaimana adanya. Sebagai pendekatan dalam penelitian ini adalah pendekatan bentuk studi kasus yang menyangkut atas, seseorang, kelompok atau suatu lembaga secara cermat dan intensif.

Kasus yang diteliti dalam penelitian ini adalah pola pembentukan karakter disiplin dan tanggung jawab pada peserta didik. Sebagai rincian unit analisisnya 
adalah peran orang tua dalam membentuk karakter disiplin dan tanggung jawab pada peserta didik, peran guru dalam membentuk karakter disiplin dan tanggung jawab pada peserta didik, kolaborasi orang tua dan guru melalui kubungortu dalam membentuk karakter disiplin dan tanggung jawab peserta didik.

Prosedur pengumpulan data yang digunakan dalam penelitian kualitatif ini adalah telaah dokumen, wawancara, serta observasi. Teknik analisis data yang dilakukan dalam penelitian ini merupakan proses mencari dan mengatur secara sistematis hasil wawancara, catatan lapangan, serta dokumen yang telah dihimpun secara interaktif dan berlangsung secara terus menerus sampai tuntas, sehingga datanya jenuh. Aktivitas dalam analisis meliputi empat tahap yaitu tahap reduksi data, penyajian data, penarikan kesimpulan, dan verifikasi.

\section{HASIL PENELITIAN DAN PEMBAHASAN}

\section{Hasil Penelitian}

Terdapat peran orang tua dan guru dalam meningkatkan karakter disiplin dan tanggung jawab peserta didik dalam kolaborasi orang tua dan guru melalui buku penghubung orang tua yang dalam tulisan ini disebut dengan kubungortu.

a. Peran Orang Tua dalam Meningkatkan Karakter Disiplin dan Tanggung Jawab Peserta Didik

Pendidikan karakter yang dilakukan orang tua diawali dengan penanaman karakter kemudian pemeliharaan. Pemeliharaan yang dilakukan orang tua adalah pembiasaan waktu belajar dan tidak memegang hp. Temuan dari hasil wawancara, observasi, dan dokumentasi terkait pemeliharaan orang tua terhadap peningkatan karakter disiplin dan tanggung jawab peserta didik adalah sebagai berikut.

1) Orang tua mengenalkan dan menanamkan karakter disiplin dan tanggung jawab dengan memberi jadwal waktu belajar di rumah.

2) Orang tua membiasakan anak belajar sesuai jadwal yang sudah dibuat.

3) Orang tua selalu mendampingi, mengawasi, memonitoring kemudian melaporkan kegiatan belajar anak di rumah melalui buku penghubung orang tua. 
b. Peran Guru dalam Meningkatkan Karakter Disiplin dan Tanggung Jawab Peserta Didik

Pendidikan karakter yang dilakukan guru memberikan teladan karakter yang baik kepada peserta didik. Peserta didik pada usia sekolah dasar sangat membutuhkan aturan, bimbingan dan batasan yang jelas untuk menjadi pedoman perilaku yang baik. Berikut ini temuan hasil wawancara, observasi, dan dokumentasi terkait menanamkan karakter disiplin dan tanggung jawab peserta didik.

1) Guru memberikan contoh-contoh perilaku disiplin dan tanggung jawab.

2) Guru menunjukkan penghargaan kepada peserta didik yang telah melakukan disiplin dan tanggung jawab yang baik.

3) Guru mendorong peserta didik untuk memiliki disiplin dan tanggung jawab untuk mengikuti aturan yang telah ditetapkan.

4) Guru mengkomunikasikan melalui buku penghubung orang tua dan POS (paguyuban orang tua siswa).

c. Kolaborasi Orang Tua dan Guru dalam Membentuk Karakter Disiplin dan Tanggung Jawab Peserta Disik SD Negeri Delegan 3

Dua indikator permasalahan yaitu peran orang tua dan guru dalam membentuk karakter disiplin dan tanggung jawab peserta didik, strategi pembentukan karakter disiplin dan tanggung jawab peserta didik. Kolaborasi orang tua dan guru meningkatkan karakter disiplin dan tanggung jawab peserta didik dengan strategi menggunakan buku penghubung orang tua sebagai komunikasi menunjukkan peningkatan karakter disiplin dan tanggung jawab peserta didik.

\section{Pembahasan}

Hal di atas memiliki persamaan dengan hasil penelitian yang dilakukan oleh Bisri (2016) yang menyebutkan bahwa keterlibatan orang tua sangat penting terutama dalam pendidikan anak. Kerja sama kemitraan antara orang tua dan lembaga pendidikan anak usia dini merupakan suatu hal yang mutlak, demi mengoptimalkan perkembangan anak secara utuh dan menyeluruh. 
Peran orang tua terhadap peserta didik dalam meningkatkan karakter disiplin dan tanggung jawab yang pertama adalah sebagai manager atau pemimpin dalam keluarga yang bertugas merencanakan, melaksanakan, mengawasi dan merefleksi dengan buku penghubung orang tua. Kedua, peran orang tua dalam membentuk karakter disiplin dan tanggung jawab peserta didik adalah sebagai teladan yaitu orang tua dengan pola asuhnya memberikan teladan bagi terbentuknya karakter disiplin dan tanggung jawab peserta didik. Ketiga, peran orang tua sebagai fasilitator yaitu orang tua memberikan fasilitas yang diperlukan dalam pendidikan peserta didik meliputi kebutuhan primer, sekunder, dan kebutuhan penunjang lainnya. Keempat, peran orang tua sebagai motivator yaitu memberikan semangat kepada peserta didik untuk berkarakter disiplin dan tanggung jawab. Kelima, orang tua berperan sebagai inspirator yaitu memberikan semangat untuk mengembangkan diri sesuai dengan potensi yang dimiliki peserta didik.

Indikator permasalahan kedua memiliki kesamaan dengan penelitian Hasan Bisri yaitu peran guru dalam meningkatkan karakter disiplin dan tanggung jawab peserta didik. Pertama, peran guru sebagai katalisator ditunjukkan dengan disiplin kehadiran, ketepatan jam mengajar, ketepatan jam pulang, dan kedisiplinan mematuhi tata tertib yang berlaku di sekolah. Kedua, peran guru sebagai kreator ditunjukkan dengan menciptakan tata tertib sekolah, menciptakan kegiatan sekolah yang mengarah pada usaha pembudayaan disiplin seperti kegiatan sholat berjama'ah dhuhur untuk guru, peserta didik, dan karyawan, kegiatan ekstrakurikuler dan sebagainya. Ketiga, peran guru sebagai motivator ditunjukkan dalam beragai kegiatan di antaranya ketika pembelajaran di kelas, kegiatan upacara bendera, kegiatan senam bersama. Keempat, peran guru sebagai evaluator ditunjukkan dengan peraturan mewajibkan peserta didik membawa buku penghubung orang tua untuk mengetahui dan mengontrol kedisiplinan dan tanggung jawab peserta didik. Kelima, peran guru sebagai inspirator ditunjukkan pada tingkah laku guru yang memperlihatkan disiplin dan tanggung jawab setiap hari. 
Indikator ketiga kolaborasi orang tua dan guru dalam meningkatkan karakter disiplin dan tanggung jawab peserta didik. Kolaborasi antara orang tua dan guru melalui paguyuban dan komunikasi buku penghubung orang tua memberikan dampak yang positif. Kondisi awal orang tua kurang peduli mendampingi peserta didik belajar di rumah dengan adanya program komunikasi selain paguyuban yaitu dengan buku penghubung orang tua, karakter disiplin dan tanggung jawab peserta didik meningkat. Terbukti dengan kondisi awal peserta didik hampir setiap hari setiap kelas ada yang tidak mengerjakan tugas/PR, tidak membawa buku, dengan adanya program buku penghubung orang tua, persentase peserta didik yang tidak mengerjakan PR dan tidak membawa buku menjadi berkurang.

\section{SIMPULAN}

Peran orang tua peserta didik dalam meningkatkan karakter disiplin dan tanggung jawab peserta didik di rumah adalah proaktif yaitu dengan strategi mengenalkan, menanamkan, dan membiasakan karakter disiplin dan tanggung jawab peserta didik dengan membuat jadwal belajar di rumah dan mengomunikasikan melalui kubungortu. Peran guru dalam meningkatkan karakter disiplin dan tanggung jawab peserta didik di sekolah adalah memberikan teladan, penghargaan, dan membiasakan melalui kegiatan-kegiatan pembiasaan yang menumbuhkan kegiatan disiplin dan tanggung jawab serta mengkomunikasikan melalui kubungortu. Kolaborasi orang tua dan guru dalam meningkatkan karakter disiplin dan tanggung jawab peserta didik secara langsung dan tidak langsung terjalin baik. Dikatakan terjalin baik karena terbukti dengan peran aktif orang tua peserta didik dalam mendukung program-program sekolah seperti POS (Paguyuban Orang Tua Siswa) dan buku penghubung orang tua. Hal ini berdampak pada peningkatan karakter disiplin dan tanggung jawab peserta didik.

\section{DAFTAR PUSTAKA}

Barnawi \& Arifin, M. (2017). Strategi dan Kebijakan Pembelajaran Pendidikan Karakter. Yogyakarta: Ar-Ruzz Media. 
Bisri, H. (2016). Kolaborasi Orang Tua dan Guru dalam Membentuk Karakter Disiplin dan Jujur pada Anak Didik. Diakses dari etheses.uin-malang.ac.id Depdiknas. (2003). Undang-undang No. 20 Tahun 2003 tentang Sistem Pendidikan Nasional. Jakarta: Depdiknas

Hendarman. (2019). Pendidikan Karakter Era Milenal. Bandung: PT Remaja Rosdakarya.

Hudiyono. (2012). Membangun Karakter Siswa. Surabaya: Esensi Erlangga Group.

Husdarta. (2010). Psikologi Olahraga. Bandung: Alfabeta.

Kemendikbud. (2017). Pedoman Pembinaan Nilai-Nilai Akhlak Mulia Siswa Melalui Kegiatan Ekstrakurikuler Sekolah Dasar. Jakarta: Kemendikbud Dirjen Pendidikan Dasar dan Menengah.

Kemendiknas. (2010). Kebijakan Nasional Pembangunan Karakter Bangsa. Jakarta: Kemendiknas.

Kurniawan, S. (2017). Pendidikan Karakter. Yogyakarta: Ar-Ruzz Media.

Mulyana, D. (2002). Metodologi Penelitian Kualitatif. Bandung: PT Remaja Rosdakarya.

Samani, M. (2013). Konsep dan Model Pendidikan Karakter. Bandung: PT Rosdakarya.

Walgito, B. 2010. Pengantar Psikologi Umum. Yogyakarta: Andi Offset 